\title{
Research on lower extremity health in patients with multiple sclerosis: a systematic scoping review
}

\author{
Minna Stolt ${ }^{1 *}$ (D), Anne-Marie Laitinen ${ }^{1,2}$, Juhani Ruutiainen ${ }^{3,4}$ and Helena Leino-Kilpi ${ }^{1,2}$ (B)
}

\begin{abstract}
Background: Multiple sclerosis (MS) often affects ambulation and the function of the lower limbs. However, little is known about how much research has been conducted on lower extremity health in patients with MS.

Objective: To analyse empirical studies and their evidence on lower extremity health in patients with MS, in order to identify the need for future studies in key areas.

Methods: A systematic scoping review was conducted. A literature search of Medline (PubMed), CINAHL (EBSCO) and the Cochrane Library databases was performed. The search covered the period up to 15 January 2020 from the earliest records available. This led to the inclusion of 42 empirical articles. The data were analysed using content analysis and quantification techniques.

Results: The research on lower extremity health focused primarily on two main areas: gait and lower extremity muscle strength. Lower extremity health was assessed using a variety of methods, most of which consisted of objective physical tests and gait analysis. Patients with MS had many problems with the health of their lower extremities, which manifested in walking difficulties, balance problems, muscle weaknesses and spasticity. In the feet, pes cavus, claw toes, oedema and altered foot sensation were common.

Conclusions: MS affects lower limb and foot health, and these problems can affect patients' daily lives. However, the extent of these problems is poorly understood, partly due to the dearth of research on lower limb and foot health. Therefore, further research is warranted in order to better understand the impact of MS on foot and lower limb health in everyday life.
\end{abstract}

Keywords: Multiple sclerosis, Lower extremity, Research, Review

\section{Introduction}

Multiple sclerosis (MS) is an immune-mediated disease with a wide variation in its clinical course. Most patients with MS are initially diagnosed with a relapsingremitting form of the illness, and the progression usually begins at around 40 years of age [1]. It is estimated that in 2016, there were more than 2.2 million prevalent cases of MS worldwide [2]. The highest estimates on

\footnotetext{
* Correspondence: minna.stolt@utu.fi

${ }^{1}$ Department of Nursing Science, University of Turku, 20014 Turku, Finland Full list of author information is available at the end of the article
}

prevalence per 100,000 people were for North America (167) and Western Europe (127) [2]. In a recent Finnish registry study, the mean age of patients with a new diagnosis of MS was 37.0 years (range: 15-69) and the female/male ratio was 2.6 [3].

Spasticity and weakness in the lower extremities are among the most common signs and symptoms of MS. As such, the validated Expanded Disability Status Scale (EDSS), [4] the most commonly used rating scale for disability in MS, is heavily based on the motor function of the lower limbs. Ambulatory impairment related to MS

C C The Author(s). 2020 Open Access This article is licensed under a Creative Commons Attribution 4.0 International License, which permits use, sharing, adaptation, distribution and reproduction in any medium or format, as long as you give appropriate credit to the original author(s) and the source, provide a link to the Creative Commons licence, and indicate if changes were made. The images or other third party material in this article are included in the article's Creative Commons licence, unless indicated otherwise in a credit line to the material. If material is not included in the article's Creative Commons licence and your intended use is not permitted by statutory regulation or exceeds the permitted use, you will need to obtain permission directly from the copyright holder. To view a copy of this licence, visit http://creativecommons.org/licenses/by/4.0/ The Creative Commons Public Domain Dedication waiver (http://creativecommons.org/publicdomain/zero/1.0/) applies to the data made available in this article, unless otherwise stated in a credit line to the data. 
is a major factor in reducing patients' quality of life and their ability to perform daily activities. Approximately $75 \%$ of patients with MS have limitations with walking [5] and balance [6-8]. Using prospective measures, fall rates of $56 \%$ have been reported in a recent metaanalysis of 537 individuals, with $37 \%$ of the study population falling recurrently [9]. Moreover fear of falling is associated with recurrent falls in patients with MS [10] thus impacting mobility and independent living. Also external factors like poorly fitting footwear increases risk for falls in patients with MS [11].

Investigations into the functional ability of patients with MS have focused on walking, postural control [7-9, $12]$ and gait abnormalities $[13,14]$. Interventions including physical exercise, orthotic therapy and electrical stimulation have been shown to decrease the risk of falls, [15-17] although the evidence regarding the effects of these interventions is sparse and uncertain [18]. However, the majority of the research seems to focus on the musculoskeletal system as a whole, rather than the lower extremities in particular. In this review, "lower extremity health' refers to the structure and functions of the lower extremities from the hips to the toes.

With regard to the lower extremities, muscle strength, optimal alignment of the joints, and foot and ankle stability form the basis for safe walking and motion [19]. However, despite the importance of lower extremity health, many persons have foot problems. In the general population, foot pain, $[20,21]$ hallux valgus, $[22,23]$ flat foot [24] and skin and nail problems [25] are the most common issues. Lower extremity health and the related problems have been considered in many patient groups with longterm health conditions such as diabetes, [26, 27] rheumatoid arthritis [28] and lupus [29]. For example, patients living with diabetes have an increased risk of developing foot problems such as neuropathic ulcers [30]; therefore, the number of foot problems in diabetic patients is higher than in the general population [31].

However, there seems to be a paucity of existing reviews examining foot problems in patients with MS.

Foot problems can add to a patient's level of disability by causing changes in the structure and function of the body. Functional loss in the hips, knees, ankles or feet significantly increase the risk of falls, especially in older people [32]. Toe deformities, such as hallux valgus, hammer toe and claw toes, reduce the area used for balance in the sole of the foot, increasing postural sway and risk of falls [32, 33] and decreasing gait velocity [34]. In addition, reduced medial arch height and forefoot disorders (such as splay foot) change the kinematics and muscle activation of the foot, leading to altered gait patterns $[35,36]$. Prolonged foot pain is also a strong risk factor for falls [37] and is associated with functional limitation, resulting in challenges conducting activities of daily living [38]. Among patients with MS, foot drop symptom where dorsiflexion of the ankle joint is reduced during gait is common [39]. Foot drop leads to poor foot clearance during gait and significantly elevates the risk of trips and falls [39]. Overall, foot problems negatively impact daily life and reduce quality of life [20,40].

Although it is understood that MS causes ambulatory impairment, little is known about lower extremity health of those living with the disease. Investigations into lower extremity health will create opportunities to develop interventions that support functional ability. The research on lower extremity health among patients with MS seems to be fragmented, however, and a thorough synthesis of the research evidence is lacking. Therefore, a systematic scoping review was conducted in order to identify the potential size and scope of the available research evidence on lower extremity health in patients with MS.

\section{Aim}

The aim of this review was to analyse empirical studies and their evidence on lower extremity health in patients with MS, in order to identify the need for future studies in key areas.

The following research questions were formulated:

1) What is the focus of lower extremity health research in patients with MS?

2) What methods have been used to study lower extremity health in patients with MS?

3) What are the main lower extremity problems in patients with MS?

\section{Methods}

A systematic scoping review [41] was conducted. The Preferred Reporting Items for Systematic Reviews and Meta-Analyses (PRISMA) extension for scoping reviews [42] was used to outline this review. The review followed predetermined, unpublished, protocol.

\section{Literature search}

A literature search was performed in three international scientific databases - Medline (PubMed) and CINAHL (EBSCO) - and the Cochrane Library. The search covered the period between 15 January 2020 and the earliest records available: from 1966 for Medline/PubMed, from 1988 for CINAHL and from 1992 for the Cochrane Library. Medical Subject Headings (MeSH terms, in Medline and Cochrane Library) and Major Headings (in CINAHL) were used to identify studies focusing on MS. Multiple search terms were used in order to cover the topic of lower extremity health as widely as possible. The final search sentence was as follows: Multiple sclerosis[MeSH] AND (foot OR feet OR "lower extremity" 
OR "lower extremities" OR "lower leg" OR "lower legs" OR "lower limb" OR "lower limbs") AND (health OR problem* OR disorder* OR complaint* OR deformit* OR disabilit* OR condition*). The search was limited to title and abstract levels and to studies published in English. The literature search produced a total of 446 hits ( $n=387 /$ Medline, $n=56 /$ CINAHL, $n=3 /$ Cochrane).

\section{Study retrieval process}

The studies were assessed against predetermined eligibility criteria (Table 1 ). The study retrieval process was carried out by two researchers (A-ML, MS) in two phases (Fig. 1). First, the titles and abstracts of the studies were screened against the inclusion and exclusion criteria. The researchers worked independently and discussed their choices before the next phase. In the case of a disagreement, this was discussed and a consensus was achieved within the research team. In total, 328 studies were excluded because they did not focus on lower extremity health or they were instrument-development or instrument-validation studies. The remaining 73 studies were included in the second phase, which entailed a full inspection of the text. After careful reading of the full texts and achieving a consensus, 31 studies were excluded. This resulted in 42 studies being included in the review and the final analysis.

\section{Data extraction and analysis}

For the data extraction, detailed information from the studies were collected and entered on a data extraction spreadsheet. The information consisted of the following: author names, year of publication, country of origin, study aim, study setting, study design, methods of data collection and analysis, participants (sample size, mean age), and main results. The data were analysed using content analysis and quantification. The original expressions in the studies were used, which removed the need for any interpretation.

\begin{tabular}{l} 
Table 1 Eligibility criteria \\
\hline Inclusion criteria: \\
• empirical study \\
- adult patients with MS as research informants \\
- focus on foot or lower extremity health or functions or on walking \\
(measured using non-invasive methods) \\
Exclusion criteria: \\
- review or theory articles \\
- focus on the outcomes of foot or lower extremity surgery \\
- pharmacological studies or used only invasive methods, such as \\
electrical stimulation \\
- instrument-validation, feasibility or case studies
\end{tabular}

Critical appraisal of individual sources of evidence

Critical appraisal of included studies was performed using the Mixed Methods Appraisal Tool (MMAT) [43] by two authors (MS, A-ML). The MMAT is applicable for empirical studies using different research designs namely qualitative research, randomized controlled trials, non-randomized studies, quantitative descriptive studies, and mixed methods studies. Each study was evaluated against five items focusing on methodological quality of the study with response scale yes/no/can't tell.

\section{Results}

\section{Description of the studies}

The studies were published between 1978 and 2019, predominantly in the 2010s $(n=32)$. They were published in the United States $(n=15)$, Italy $(n=5)$, Australia $(n=2)$, Denmark $(n=2)$, Israel $(n=2)$, Romania $(n=2)$, Switzerland $(n=2)$, Turkey $(n=2)$ and the United Kingdom (UK) $(n=2)$. In each of the following countries, one study was published: Belgium, Brazil, Finland, France, Greece, Qatar and Spain. In addition, one study [44] included participants from five countries: France, Germany, Italy, Spain and the UK. The number of participants in each study ranged from 8 to 2171 (mean 97, median 29, SD 335). Only four of the studies included more than 100 subjects. All of the participants were patients who had been diagnosed with MS, and more information about the participants was provided in some of the studies, such as the stage of MS (relapsing-remitting or progressive) or their level on the EDSS (e.g., 2.5-5.5 or 4.0-6.0). Most of the studies used some sort of intervention design $(n=16)$ (such as randomized controlled trials, clinical trials or pretest-posttest studies) or cross-sectional design $(n=13)$. In 15 of the studies, no information was provided about the study design.

Based on critical appraisal the methodological quality of studies was acceptable. Studies with randomized controlled trial designs fulfilled all five criteria in three studies and seven studies met four criteria. In nonrandomized studies one study fulfilled all five criteria and seven studies four criteria. For quantitative descriptive studies four studies met all five criteria, sixteen studies met four and three studies met three criteria.

\section{The focus of lower extremity health research in patients with MS}

The research on lower extremity health focused primarily on two main areas: gait and lower extremity muscle strength (Table 2). The topics within the area of gait included walking endurance, gait parameters, foot placement during walking, balance and falls. The research on lower extremity muscle strength concentrated on analysing the muscle performance and capacity of the lower extremities during exercise or resistance training. There 


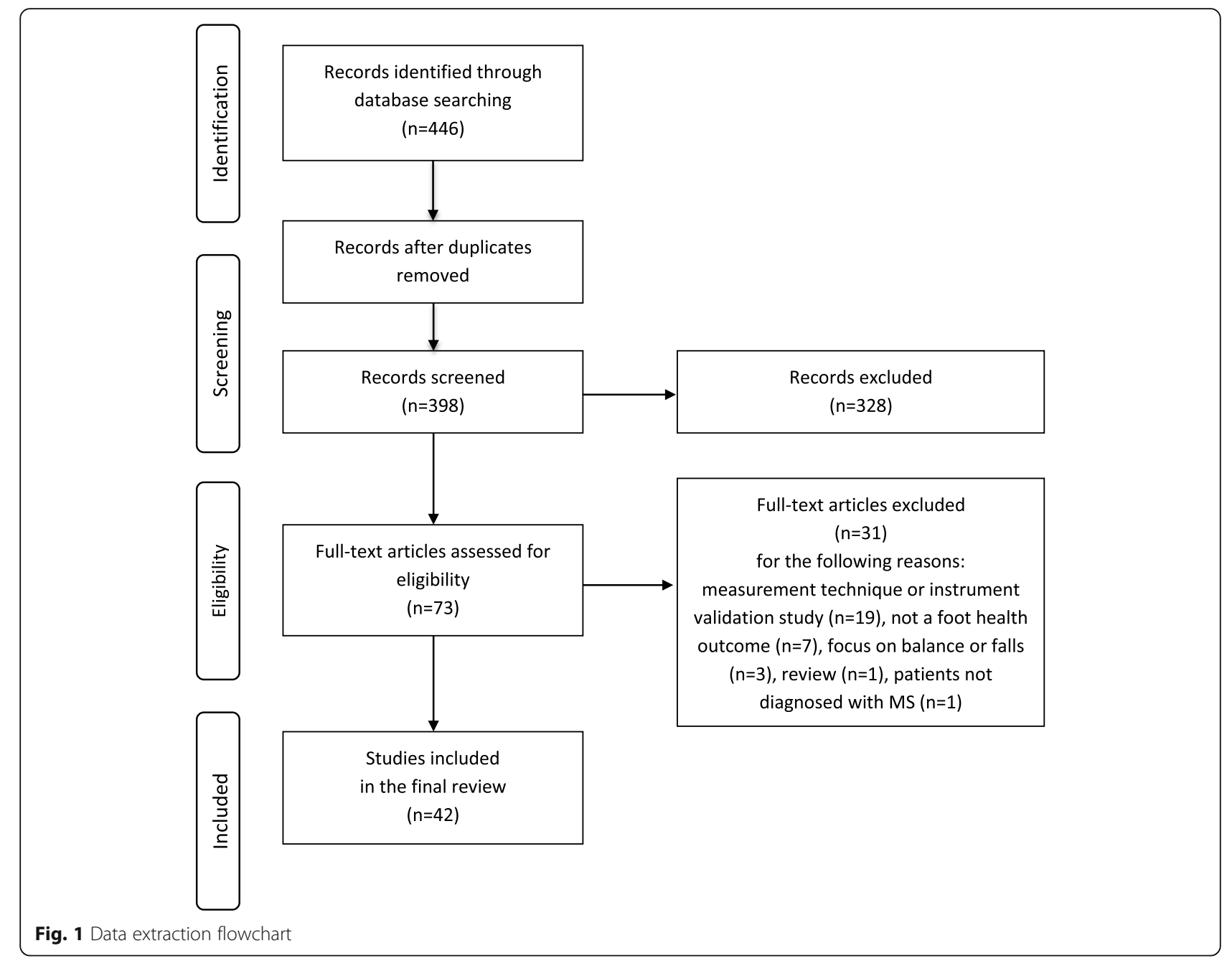

were single studies focusing on foot sensation, [50] foot vibration perception, [50,60] neuropathic foot pain, [60] foot deformities, [75] lower limb oedema [80] and foot sudomotor function [60].

\section{Methods used to study lower extremity health in patients with MS}

Lower extremity health was assessed using several different methods, most of which consisted of objective physical tests and gait analysis (Table 3). Mobility was assessed by conducting validated performance tests, such as a timed up-and-go test $(n=9)$, a timed 25 - $\mathrm{ft}$ walk $(n=14)$ or a $500-\mathrm{m}$ walk $(n=1)$. Aerobic capacity and endurance were measured with a 6 -min walk test $(n=8)$ or a one-legged cycling test $(n=1)$. Gait was assessed from the perspective of gait biomechanics conducted using $3 \mathrm{D}$ or visual gait analysis methods. The gait analysis focused on walking speed $(n=15)$ including pelvic and hip kinematics, step width and walking velocity. Gait ability was assessed using a 2 -min walk test $(n=5)$, a 10 -m walk $(n=2)$, a stair climb test $(n=2)$ and Bessou's locometer $(n=1)$, or by using the patient-reported Multiple Sclerosis Walking Scale $(n=6)$.

Lower extremity muscle strength was assessed using clinical strength tests (Table 3 ). These included isokinetic $(n=3)$ or isometric $(n=9)$ dynamometry measures and the sit-to-stand test $(n=1)$. Three studies used a dynamometer to assess muscle strength without specifying the measurement focus. Muscle endurance was assessed by counting the repetitions conducted during a 3 -min stepping test $(n=1)$ or on a seated leg-press machine. Muscle stiffness and spasticity were assessed using validated instruments, such as the Ashworth Scale $(n=$ 3). Tests focusing on tendon reflexes, passive and dynamic range of motion in ankle and knee joints and resistance were also used to test muscle spasticity.

Balance was assessed using clinical tests and instruments (Table 3). Dynamic and static balance were measured with stabilometry and posturography $(n=4)$. Obstacle negotiation was used to measure balance in obstacle-crossing $(n=1)$. Postural control was measured by timing the duration of standing on one leg $(n=1)$. 
Table 2 Summary of the studies $(n=42)$ included on the review in the alphabetical order

\begin{tabular}{|c|c|c|c|c|c|}
\hline $\begin{array}{l}\text { Author, } \\
\text { year, } \\
\text { country }\end{array}$ & Aim & Design, sample & Data collection method & Main results & $\begin{array}{l}\text { Quality appraisal } \\
\text { (number of } \\
\text { fulfilled criteria) }\end{array}$ \\
\hline $\begin{array}{l}\text { Boes et al. } \\
2018, \\
\text { USA [45] }\end{array}$ & $\begin{array}{l}\text { To determine whether a } \\
\text { powered ankle-foot orthosis } \\
\text { (AFO) that provides dorsiflexor } \\
\text { and plantar flexor assistance at } \\
\text { the ankle can improve walking } \\
\text { endurance of persons with } \\
\text { multiple sclerosis }\end{array}$ & $\begin{array}{l}\text { Short-term } \\
\text { intervention; } \\
n=16 \text { PWMS, } \\
\text { mean age } 54.6\end{array}$ & Walking test & $\begin{array}{l}\text { Powered ankle-foot orthosis } \\
\text { did not improve endurance } \\
\text { walking performance. }\end{array}$ & 4 \\
\hline $\begin{array}{l}\text { Boudarham } \\
\text { et al. } \\
2016 \text {, } \\
\text { Switzerland } \\
\text { [46] }\end{array}$ & $\begin{array}{l}\text { To assess coactivation of } \\
\text { agonist and antagonist } \\
\text { muscles at the knee and ankle } \\
\text { joints during gait in patients } \\
\text { with multiple sclerosis, and to } \\
\text { evaluate the relationship } \\
\text { between muscle coactivation } \\
\text { and disability, gait } \\
\text { performance, dynamic ankle } \\
\text { strength measured during gait, } \\
\text { and postural stability. }\end{array}$ & $\begin{array}{l}\text { Design not } \\
\text { reported; } \\
n=14 \text { PWMS, } \\
\text { mean age } 51\end{array}$ & 3D-gait analysis & $\begin{array}{l}\text { Coactivation was increased in } \\
\text { the knee muscles during } \\
\text { single support (proximal } \\
\text { strategy) and in the ankle } \\
\text { muscles during double } \\
\text { support (distal strategy). The } \\
\text { magnitude of coactivation was } \\
\text { highest in the patients with } \\
\text { the slowest gait, the greatest } \\
\text { motor impairment and the } \\
\text { most instability. }\end{array}$ & 3 \\
\hline $\begin{array}{l}\text { Bowser } \\
\text { et al. 2015, } \\
\text { USA [47] }\end{array}$ & $\begin{array}{l}\text { To compare sit-to-stand bio- } \\
\text { mechanics among three } \\
\text { groups: people with multiple } \\
\text { sclerosis who exhibit leg weak- } \\
\text { ness, people with multiple } \\
\text { sclerosis who have comparable } \\
\text { strength to controls, and } \\
\text { healthy controls. }\end{array}$ & $\begin{array}{l}\text { Cross-sectional } \\
\text { design; } \\
n=21 \text { PwMS } \\
\text { divided in two } \\
\text { groups: } \\
\text { Leg weakness } \\
\text { group } n=10, \\
\text { mean age } 49.2 \\
\text { Comparable } \\
\text { strength group } \\
n=11, \text { mean age } \\
39.8\end{array}$ & $\begin{array}{l}\text { Lower extremity muscle } \\
\text { strength }\end{array}$ & $\begin{array}{l}\text { Persons with multiple sclerosis } \\
\text { exhibiting leg weakness } \\
\text { displayed decreased leg } \\
\text { strength, greater trunk flexion, } \\
\text { faster trunk flexion velocity } \\
\text { and decreased knee extensor } \\
\text { power compared to the other } \\
\text { two groups, and slower rise } \\
\text { times compared to controls. }\end{array}$ & 3 \\
\hline $\begin{array}{l}\text { Brincks et al. } \\
2017, \\
\text { Denmark } \\
{[48]}\end{array}$ & $\begin{array}{l}\text { To examine the associations } \\
\text { between postural balance, } \\
\text { assessed by force platform } \\
\text { stabilometry, and complex } \\
\text { walking performance and }\end{array}$ & $\begin{array}{l}\text { Cross-sectional } \\
\text { study design; } \\
n=13 \text { PwMS, } \\
\text { mean age } 42\end{array}$ & $\begin{array}{l}\text { Walking performance, postural } \\
\text { balance }\end{array}$ & $\begin{array}{l}\text { Significant correlations were } \\
\text { observed between sway area } \\
\text { and Timed Up \& Go and } \\
\text { fastest safe walking speed in } \\
\text { persons with MS. }\end{array}$ & 4 \\
\hline
\end{tabular}

maximal walking speed in mildly disabled persons with MS and healthy matched controls.

Broekmans To investigate the acute

et al.

2010,

Belgium

[49] effects of long-term wholebody vibration on leg muscle performance and functional capacity in persons with multiple sclerosis.

Citaker et al. To investigate the relationship 2011, between the foot sensations

Turkey [50] and standing balance in $\begin{array}{ll}\text { and standing balance in } & n=27 \text { PwMS, } \\ \text { patients with Multiple Sclerosis } & \text { mean age } 36.74\end{array}$ (MS) and find out the sensation, which best predicts balance.

Citaker et al. To investigate the relationship 2013, between the lower extremity

Turkey [51] isometric muscle strength and standing balance in patients with MS.
A randomized controlled trial; $n=25$ PwMS, mean age 47.9

\section{Design not} reported;

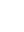

Design not reported; $n=47$ PwMS, mean age 36.98
Muscle maximal isometric and Leg muscle performance and dynamic strength, strength functional capacity were not endurance and speed of altered following 10 or 20 movement, function. weeks of whole-body vibration.

Sensation, vibration sensation, Light touch-pressure, vibration, 4 standing on one-leg

Neurological disability, muscle strength, static one-leg standing balance

two-point discrimination sensations of the foot sole, and duration of one-leg standing balance were decreased in patients with MS. Sensation of the foot sole was related with duration of one-leg standing balance in patients with MS.

Hip flexor-extensor-abductoradductor, knee flexor-extensor, and ankle dorsal flexor isometric muscle strength, and duration of one-leg standing balance were decreased in patients with MS. All assessed lower extremity isometric muscle strength and EDSS 
Table 2 Summary of the studies $(n=42)$ included on the review in the alphabetical order (Continued)

\begin{tabular}{|c|c|c|c|c|c|}
\hline $\begin{array}{l}\text { Author, } \\
\text { year, } \\
\text { country }\end{array}$ & Aim & Design, sample & Data collection method & Main results & $\begin{array}{l}\text { Quality appraisa } \\
\text { (number of } \\
\text { fulfilled criteria) }\end{array}$ \\
\hline
\end{tabular}

DeBolt et al. To examine the effects of an

2004,

USA [52]

8-week home-based resistance exercise program on balance, power, and mobility in adults with multiple sclerosis.
Pretest-posttest experimental group design; $n=29$ female PWMS, mean age 50.3

$n=8$ male PwMS, mean age 51.1

divided into exercise group and control group

Dodd et al. To determine the effectiveness Single blind 2011 of progressive resistance randomized Australia training (PRT) for people with controlled trial; [53] MS, focusing on improving the gait deficits common in this population.

\section{experimental}

group $n=36$ PwMS, mean age 47.7

control group $n=$ 35 PwMS, mean age 50.4

Fritz et al. To determine the longitudinal Longitudinal

2015,

USA [54]$$
\text { relationships among }
$$

quantitative measures of gait cohort study; $n=57$ PwMS, and balance in individuals with mean age 45.86 MS.

Gutierrez et al. 2005, USA [55]

To evaluate the effects of an 8week lower-body resistancetraining program on walking mechanics in persons with multiple sclerosis (MS)

Hayes et al. To assess the effects of a 2011, USA [18] program of high-intensity RENEW exercise combined with standard exercises on lower extremity strength, mobility, balance, and fatigue in individuals with MS compared to a standard exercise program over 12 weeks.

Huisinga To determine any differences et al. 2013, in biomechanical gait USA [56]
Repeatedmeasures design; $n=8$ PwMS, mean age 46.0

A prospective, longitudinal, randomized intervention trial; $n=19$ PwMS mean age 49

Quantitative evaluation; $n=31$ PWMS
Balance, mobility, leg power

level were related duration of one-leg standing balance in patients with MS. All assessed lower extremity isometric muscle strength (except ankle dorsal flexor) was related with EDSS.

Leg extensor power improved 4 significantly in the exercise group, although measures of balance and mobility did not change.

Walking endurance, maximal self-reported disability tended strength, walking or balance. walking speed, muscle strength, muscle endurance, self-reported fatigue, healthrelated quality of life, muscle stiffness and spasm

No differences were detected in walking performance. PRT demonstrated increased leg press strength, increased reverse leg press strength, and increased muscle endurance of the reverse leg press.

Balance, walking, muscle strength, vibration

Increases in static posturography and reductions in dynamic posturography are associated with a decline in walk velocity and Timed $25-$ Foot Walk performance over time.

Kinematic gait parameters, Resistance training increased isometric strength,3-min significantly percentage of stepping, fatigue, self-reported stride time in the swing phase, disability

step length, stride length, and foot angle; and significantly decreased percentage of stride time in the stance and doublesupport phases, duration of the double-support phase, and toe clearance. Isometric leg strength improved in 2 of the 4 muscle groups tested. Fatigue indices decreased, whereas to decrease following the training program.

No significant time effects or interactions were observed for
Lower extremity strength, walking, balance, fatigue
4

4

(1)


Table 2 Summary of the studies ( $n=42$ ) included on the review in the alphabetical order (Continued)

\begin{tabular}{|c|c|c|c|c|c|}
\hline $\begin{array}{l}\text { Author, } \\
\text { year, } \\
\text { country }\end{array}$ & Aim & Design, sample & Data collection method & Main results & $\begin{array}{l}\text { Quality appraisa } \\
\text { (number of } \\
\text { fulfilled criteria) }\end{array}$ \\
\hline
\end{tabular}

\begin{tabular}{|c|c|c|}
\hline & with MS and healthy controls. & mean age 46.2 \\
\hline $\begin{array}{l}\text { Jackson } \\
\text { et al. 2008, } \\
\text { USA [57] }\end{array}$ & $\begin{array}{l}\text { To evaluate the acute effects } \\
\text { of a brief exposure to WBV on } \\
\text { quadriceps and hamstring } \\
\text { muscle performance in } \\
\text { persons with MS }\end{array}$ & $\begin{array}{l}\text { Randomized, } \\
\text { crossover study; } \\
n=15 \text { PwMS, } \\
\text { mean age } 54.6\end{array}$ \\
\hline
\end{tabular}

Kalron

$2017 \mathrm{a}$

Israel [58]

A cross-sectional study;

$N=436$ PwMS divided into two groups:

$n=258$ normal weight, mean age 40.4

$n=178$ obese, mean age 49.6

Kalron

2017b, Israel [59]

Khan et al.

2018,

Qatar [60]

To determine the prevalence and severity of neuropathic pain, sudomotor dysfunction and abnormal vibration perception in patients with MS

Kjolhede To investigate the relationship et al. 2015, Denmark between rate of force development (RFD) and maximal muscle strength of knee extensors and flexors and measures of functional capacity in PwMS

Larson et al. To quantify bilateral

2013, differences in lower-limb per-

Greece [62] formance and metabolism during exercise.

McLoughlin To investigate the effect of

et al. walking-induced fatigue on

2014,

Australia lower limb strength and postural sway in people with

[63] moderately disabling MS.

Cross-sectional study;

$N=91$ PwMS

mean age 48.0

divided into two

groups:

$n=50$ fallers,

mean age 48.8

$n=41$ non-fallers

mean age 46.7

years

Design not reported;

$n=73$ PwMS,

mean age 36.68

Clinical trial;

$n=35$ PwMS,

Design not

reported:

$n=8$ PwMS, mean

age 51.6

Controlled study;

$n=34$ PwMS

mean age 49.1
Muscle torque

mean age 43.3

Fatigue, postural sway, lower limb strength

Disability, neuropathic pain, sudomotor function, vibration perception threshold

Muscle strength, walking, stair climb, functional capacity

Muscle strength, walking

patiotemporal parameters of gait, postural control

Gait measures

with MS. Significant

correlations between

biomechanical gait parameters

and EDSS score.

There were no significant differences in isometric torque production between the 2and $26-\mathrm{Hz}$ WBV conditions. There was also no significant difference between baseline torque values and those measured at one, 10, and $20 \mathrm{~min}$ after either vibration exposure.

Obese subjects walked significantly slower, with shorter step lengths and a wider step width. Thy walked a shorter distance on the 6Minute Walk test and slower on the Timed 25-Foot Walk test.

The MS fallers presented a higher variability score in the step length and single support compared to participants in the non-fallers. Gait variability scores were significantly correlated with clinical walking tests.

Patients with multiple sclerosis 4 have evidence of sudomotor dysfunction and elevated vibration perception.

Rate of force development and maximal muscle strength correlated with functional capacity. Correlations were strongest for knee extensors and flexors of the weaker leg.

Individuals with MS had significant between-leg differences in leg strength, peak oxygen uptake, and peak workload.

Significant time by condition effects for all assessment measures indicated the sixminute walk induced fatigue with associated increases in postural sway and reductions in lower limb strength in people with MS.

No significant changes in the control group from baseline to post-intervention evaluation. In intervention study; Muscle strength $n=40$ PwMS:

divided into two

\section{5}

Medina- $\quad$ To examine the effects of 12 Perez et al. wk. of muscle power training 2016, 
Table 2 Summary of the studies ( $n=42$ ) included on the review in the alphabetical order (Continued)

\begin{tabular}{|c|c|c|c|c|c|}
\hline $\begin{array}{l}\text { Author, } \\
\text { year, } \\
\text { country }\end{array}$ & Aim & Design, sample & Data collection method & Main results & $\begin{array}{l}\text { Quality appraisal } \\
\text { (number of } \\
\text { fulfilled criteria) }\end{array}$ \\
\hline Spain [64] & $\begin{array}{l}\text { maximal voluntary isometric } \\
\text { contraction (MVIC) of knee } \\
\text { extensors in patients with MS }\end{array}$ & $\begin{array}{l}\text { groups } \\
n=20 \text { women } \\
\text { with MS, mean } \\
\text { age } 42.8 \\
n=20 \text { men with } \\
\text { MS, mean age } \\
44.0\end{array}$ & & $\begin{array}{l}\text { contrast, the exercise group } \\
\text { significantly increased MVIC } \\
\text { and muscle power after the } \\
\text { training. }\end{array}$ & \\
\hline $\begin{array}{l}\text { Motl et al. } \\
2012 \\
\text { USA }[65]\end{array}$ & $\begin{array}{l}\text { To examine changes in } \\
\text { walking function associated } \\
\text { with combined exercise } \\
\text { training consisting of aerobic, } \\
\text { resistance, and balance } \\
\text { activities in persons with MS } \\
\text { who had recent onset of gait } \\
\text { impairment }\end{array}$ & $\begin{array}{l}\text { Design not } \\
\text { reported; } \\
n=13 \text { PWMS, } \\
\text { mean age } 51.5\end{array}$ & Walking, function & $\begin{array}{l}\text { These results suggest that a } \\
\text { moderately intense, } \\
\text { comprehensive, combined } \\
\text { exercise training program } \\
\text { represents a rehabilitation } \\
\text { strategy that is associated with } \\
\text { improved walking mobility. }\end{array}$ & 4 \\
\hline $\begin{array}{l}\text { Neamtu } \\
\text { et al. 2012, } \\
\text { Romania } \\
{[66]}\end{array}$ & $\begin{array}{l}\text { To present morpho-functional } \\
\text { limb aspects during gait at MS } \\
\text { patients. }\end{array}$ & $\begin{array}{l}\text { Design not } \\
\text { reported; } \\
n=13 \text { PWMS, } \\
\text { mean age } 36\end{array}$ & $\begin{array}{l}\text { Biomechanical examination of } \\
\text { the foot }\end{array}$ & $\begin{array}{l}\text { Load and impulse had high } \\
\text { values at MS patients; these } \\
\text { patients displayed a significant } \\
\text { right-left asymmetry during all } \\
\text { the gait phases due to the } \\
\text { lower propulsion force of the } \\
\text { foot in stride. }\end{array}$ & 3 \\
\hline $\begin{array}{l}\text { Nogueira } \\
\text { et al. 2013, } \\
\text { Brazil [67] }\end{array}$ & $\begin{array}{l}\text { To analyze the gait } \\
\text { characteristics of MS patients } \\
\text { in the absence of clinical } \\
\text { disability }\end{array}$ & $\begin{array}{l}\text { Case-control } \\
\text { study; } \\
n=12 \text { PWMS, } \\
\text { mean age } 30.6\end{array}$ & $\begin{array}{l}\text { Disability, gait, perceived } \\
\text { balance confidence, physical } \\
\text { activity and fatigue }\end{array}$ & $\begin{array}{l}\text { MS patients showed } \\
\text { impairment of perceived } \\
\text { fatigue, perceived of walking } \\
\text { impact and perceived balance } \\
\text { confidence, despite having no } \\
\text { disability. }\end{array}$ & 4 \\
\hline $\begin{array}{l}\text { Pau et al. } \\
2015, \\
\text { Italy [68] }\end{array}$ & $\begin{array}{l}\text { To characterize the gait } \\
\text { patterns of individuals with } \\
\text { Multiple Sclerosis (MS) affected } \\
\text { by spasticity using quantitative } \\
\text { gait analysis. }\end{array}$ & $\begin{array}{l}\text { Cross-sectional } \\
\text { study; } \\
n=38 \text { PwMS, } \\
\text { divided into two } \\
\text { groups: } \\
n=19 \text { PwMS } \\
\text { affected by lower } \\
\text { limb spasticity, } \\
\text { mean age } 54.6 \\
n=19 \text { PwMS not } \\
\text { affected, mean } \\
\text { age } 47.1\end{array}$ & $\begin{array}{l}\text { Walking, range of motion, } \\
\text { muscular activation }\end{array}$ & $\begin{array}{l}\text { Spasticity originates a peculiar } \\
\text { gait pattern characterized by } \\
\text { reduced speed, cadence, stride } \\
\text { length, swing phase and } \\
\text { increased double support time, } \\
\text { but they also reveal specific } \\
\text { alterations in kinematics and } \\
\text { muscular activation. }\end{array}$ & 4 \\
\hline $\begin{array}{l}\text { Pau et al. } \\
2017, \\
\text { Italy [69] }\end{array}$ & $\begin{array}{l}\text { To quantitatively assess the } \\
\text { effect of } 6 \text { months of } \\
\text { supervised adapted physical } \\
\text { activity (APA i.e. physical } \\
\text { activity designed for people } \\
\text { with special needs) on spatio- } \\
\text { temporal and kinematic pa- } \\
\text { rameters of gait in persons } \\
\text { with Multiple Sclerosis (pwMS) }\end{array}$ & $\begin{array}{l}\text { Randomized } \\
\text { controlled trial; } \\
n=22 \text { PwMS, } \\
\text { were randomly } \\
\text { assigned: } \\
n=11 \\
\text { intervention } \\
\text { group, mean age } \\
47.4 \\
n=11 \text { control } \\
\text { group, mean age } \\
44.5\end{array}$ & Gait analysis, range of motion & $\begin{array}{l}\text { The training originated } \\
\text { significant improvements in } \\
\text { stride length, gait speed and } \\
\text { cadence in the intervention } \\
\text { group, while GPS and GVS } \\
\text { scores remained practically } \\
\text { unchanged. A trend of } \\
\text { improvement was also } \\
\text { observed as regard the } \\
\text { dynamic ROM of hip, knee, } \\
\text { and ankle joints. }\end{array}$ & 4 \\
\hline $\begin{array}{l}\text { Peruzzi et al. } \\
2017, \\
\text { Italy [70] }\end{array}$ & $\begin{array}{l}\text { To examine the effect of a } \\
\text { virtual reality-based training on } \\
\text { gait of people with multiple } \\
\text { sclerosis. }\end{array}$ & $\begin{array}{l}\text { Single blind } \\
\text { randomized } \\
\text { controlled trial } \\
n=25 \text { PwMS } \\
\text { divided into two } \\
\text { groups: } \\
n=11 \text { control } \\
\text { group, mean age } \\
42.0 \\
n=14 \\
\text { experimental }\end{array}$ & $\begin{array}{l}\text { Gait analysis, clinical motor } \\
\text { tests, walking endurance and } \\
\text { speed, mobility, balance, } \\
\text { obstacle negotiation, disability }\end{array}$ & $\begin{array}{l}\text { Subjects in both the groups } \\
\text { significantly improved the } \\
\text { walking endurance and speed, } \\
\text { cadence and stride length, } \\
\text { lower limb joint ranges of } \\
\text { motion and powers, during } \\
\text { single and dual task gait. } \\
\text { Subjects in the experimental } \\
\text { group also improved balance, } \\
\text { as indicated by the results of } \\
\text { the clinical motor tests. }\end{array}$ & 5 \\
\hline
\end{tabular}


Table 2 Summary of the studies ( $n=42$ ) included on the review in the alphabetical order (Continued)

\begin{tabular}{|c|c|c|c|c|c|}
\hline $\begin{array}{l}\text { Author, } \\
\text { year, } \\
\text { country }\end{array}$ & Aim & Design, sample & Data collection method & Main results & $\begin{array}{l}\text { Quality appraisa } \\
\text { (number of } \\
\text { fulfilled criteria) }\end{array}$ \\
\hline
\end{tabular}

\begin{tabular}{lll}
\hline & & group, mean ag \\
& & 43.6 \\
Picelli et al. & To compare the clinical and & Observational \\
2017, & ultrasonographic features of & study; \\
Italy [71] & spastic equinus in patients & $n=38$ PwMS, \\
& with chronic stroke and & mean age 53.2 \\
& multiple sclerosis & $n=38$ chronic \\
& & stroke patients, \\
& & mean age 61.4
\end{tabular}

Pike et al.

2012,

France,

Germany,

Italy, Spain,

the UK [44]
To evaluate the prevalence, severity and burden of walking in 5 European countries

Cross-sectional study, patient record-based study; $n=2171$ PwMS mean age 40.6 and mobility problems (WMPs)

Mobility, walking

Muscle spasticity most bothersome symptom by almost half of patients. There was a clear, independent and strong directional relationship between severity of WMPs (subjective and objective) and healthcare resource utilisation.

Patients with longer walking times (indicating greater walking impairment) were significantly more likely to require additional caregiver support, visit a variety of healthcare professionals including their primary care physicians and require more long-term non-disease modifying drug.

Ramdharry To evaluate the effects of

et al.

2006,

UK [72] dynamic foot orthoses (DFO) on walking and balance performance in people with multiple sclerosis (MS)

Remelius et al. 2012, USA [73]

To investigate (1) whether previously observed changes in gait parameters in individuals with multiple sclerosis (MS) are the result of slower preferred walking speeds or reflect adaptations independent of gait speed; and (2) the changes in spatiotemporal features of the unstable swing phase of gait in people with MS.

Renfrew

et al.

UK [74]

RiveraDomingues

et al.

1978,

USA [75]
Design not reported;

$n=16$ PwMS, age

not reported

\section{Cross-sectional}

study;

$n=19$ PWMS

mean age 51.3

Gait analysis

Walking speed, balance

Dynamic foot orthoses may increase sway and change centre of pressure position by altering foot alignment and/or plantar afferent stimulation.

Longer dual support time is part of a gait strategy in MS that is apparent even when controlling for the confounding effect of slower preferred speed.
To compare the clinical- and cost-effectiveness of ankle-foot orthoses (AFOs) and functional electrical stimulation (FES) over 12 months in people with Multiple Sclerosis with foot drop.

Multicentre,

powered, non-

blinded, random-

ized trial;

$n=85$ PwMS

divided into

$n=43 \mathrm{AFO}$

group,

$n=42$ FES device

group

To study the prevalence of the foot deformities pes cavus and claw toes found in spastic spinal cord injury and multiple sclerosis patients and to
Design not

reported;

$n=20$ PWMS

mean age 38

$n=80$ spinal cord
Walking speed improvements in walking speed at 12 months, although there were no significant
Both devices demonstrated differences in their effects.
Spasticity, foot assessment

Pes cavus and claw toes were found in two of 20 multiple sclerosis patients. All patients were spastic and had equinus deformity. 
Table 2 Summary of the studies ( $n=42$ ) included on the review in the alphabetical order (Continued)

\begin{tabular}{|c|c|c|c|c|c|}
\hline $\begin{array}{l}\text { Author, } \\
\text { year, } \\
\text { country }\end{array}$ & Aim & Design, sample & Data collection method & Main results & $\begin{array}{l}\text { Quality appraisal } \\
\text { (number of } \\
\text { fulfilled criteria) }\end{array}$ \\
\hline
\end{tabular}

\begin{tabular}{lll}
\hline & $\begin{array}{l}\text { discuss the pathogenesis of } \\
\text { these foot deformities with the } \\
\text { help of electromyography. }\end{array}$ & \multicolumn{1}{c}{ injury patients, } \\
& mean age 43
\end{tabular}

Romberg et al. 2004, Finland [77]
To improve walking and other aspects of physical function with a progressive 6-month exercise program in patients with multiple sclerosis (MS).

Rusu et al. Focus on biomechanical foot 2014,

Romania

[78]

Sandroff et al. 2013, USA [79]

Solaro et al. To evaluate the frequency of 2006, Italy [80] oedema of the lower limbs in multiple sclerosis(MS) patients utilizing a multidisciplinary approach

Sosnoff et al. 2011, USA [81]
To examine the hypothesis that persons with MS who had spasticity of the lower limbs would have more impairment of mobility and balance performance than persons with MS who did not have spasticity
Randomized controlled twocenter intervention study; $n=47$ PWMS, exercise group mean age 43.8 $n=48$ PwMS, control group, mean age 43.9

Clinical research; $n=48$ PwMS, mean age 46.04

Design not reported; $n=31$ PwMs, mean age not reported (range 18-54 years)
Walking speed, lower extremity strength, upper extremity endurance and dexterity, peak oxygen uptake, static balance.

Biomechanical foot assessment

Peak aerobic capacity, muscular strength, balance, walking performance

Design not reported; $n=205$ PwMs, mean age 50.53

Design not reported; $n=34$ PWMS mean age 57.5 mean age 57.5

Assessment for presence of oedema or cutaneous complications.

Spasticity in muscles, walking speed, mobility, walking endurance, self-reported impact of MS on walking ability, balance

\section{Design not} reported;
Gait, muscle strength
Hip passive range of motion

increased. Mean walking velocity, cadence, and posterior shear push-off force decreased. During walking, maximum ankle dorsiflexion decreased and ankle plantarflexion increased. Results suggest this 6-mo training program had minimal effect on gait abnormalities.

Change between groups was significant in the $7.62 \mathrm{~m}$ and $500 \mathrm{~m}$ walk tests. In the $7.62 \mathrm{~m}$ walk test, $22 \%$ of the exercising patients showed clinically meaningful improvements.

An instability left to right to be 4 more evident in the swing phase and it influences the under the foot impulse for the next step and postural control.

Aerobic capacity, balance, and 4 knee-extensor asymmetry were associated with walking performance and gait in persons with MS. Aerobic capacity and lower-limb strength asymmetries, but not balance, explained significant variance in walking performance and gait kinematics in the MS sample.

Ninety-three patients (45\%) showed oedema at the examination. EDSS, disease duration and disease course, but not gender, were statistically different between oedema and non-oedema patients

Fifteen participants had spasticity of the gastroc-soleus muscles based on modified Ashworth scale scores. The spasticity group had lower median EDSS scores indicating greater disability $(P=0.03)$. Mobility and balance were significantly more impaired in the group with spasticity compared to the group without spasticity.

Gait speed was reduced and strongly related to hamstring peak torque but not with 
Table 2 Summary of the studies $(n=42)$ included on the review in the alphabetical order (Continued)

\begin{tabular}{|c|c|c|c|c|c|}
\hline $\begin{array}{l}\text { Author, } \\
\text { year, } \\
\text { country }\end{array}$ & Aim & Design, sample & Data collection method & Main results & $\begin{array}{l}\text { Quality appraisal } \\
\text { (number of } \\
\text { fulfilled criteria) }\end{array}$ \\
\hline & $\begin{array}{l}\text { (MS) with particular regard to } \\
\text { patients presenting with } \\
\text { proprioceptive loss }\end{array}$ & mean age 42 years & & $\begin{array}{l}\text { quadriceps peak torque. In the } \\
\text { patients with proprioceptive } \\
\text { loss there was both a strong } \\
\text { correlation between gait } \\
\text { speed and hamstring torque } \\
\text { and a significant correlation } \\
\text { with quadriceps torque. }\end{array}$ & \\
\hline $\begin{array}{l}\text { White et al. } \\
\text { 2004, } \\
\text { USA [83] }\end{array}$ & $\begin{array}{l}\text { To evaluate the effect of an } \\
\text { eight-week progressive resist- } \\
\text { ance training programme on } \\
\text { lower extremity strength, am- } \\
\text { bulatory function, fatigue and } \\
\text { self-reported disability in mul- } \\
\text { tiple sclerosis (MS) patient }\end{array}$ & $\begin{array}{l}\text { Experimental } \\
\text { study; } \\
n=8 \text { PWMS, } \\
\text { mean age } 46\end{array}$ & $\begin{array}{l}\text { Isometric strength, walking, } \\
\text { fatigue, disability }\end{array}$ & $\begin{array}{l}\text { Knee extension, plantarflexion } \\
\text { and stepping performance } \\
\text { increased significantly. Self- } \\
\text { reported fatigue decreased } \\
\text { and disability tended to de- } \\
\text { crease following the training } \\
\text { programme. }\end{array}$ & 4 \\
\hline $\begin{array}{l}\text { Yildiz et al. } \\
2012, \\
\text { Switzerland } \\
{[84]}\end{array}$ & $\begin{array}{l}\text { To identify the relevance and } \\
\text { impact of walking speed (WS) } \\
\text { over a short distance on } \\
\text { activities of daily living (ADLs) } \\
\text { in patients with multiple } \\
\text { sclerosis (MS). }\end{array}$ & $\begin{array}{l}\text { Survey study; } \\
n=112 \text { PwMS, } \\
\text { mean age not } \\
\text { reported }\end{array}$ & Impact of MS on walking & $\begin{array}{l}\text { Half of participants reported a } \\
\text { high impact of MS on their } \\
\text { general walking ability and } \\
\text { their ability to increase WS } \\
\text { over a short distance. Up to } \\
53 \% \text { of participants reported } \\
\text { avoiding ADLs because of } \\
\text { concerns about WS. }\end{array}$ & 5 \\
\hline
\end{tabular}

The centre of pressure in the sole of the foot was analysed in order to detect changes in plantar pressure $(n=$ 2). The Activities-specific Balance Confidence Scale $(n=$ $3)$ and the Berg Balance Scale $(n=4)$ were used as objective measures of balance problems in daily life.

Specific foot assessments (Table 3) focused on vibration perception in the sole of the foot $(n=3)$, foot biomechanics $(n=2)$, plantar pressure $(n=2)$, neuropathic pain $(n=1)$, sudomotor function $(n=1)$, oedema $(n=1)$, foot sensation $(n=1)$ and foot deformities $(n=1)$.

\section{Lower extremity problems in patients with MS}

There were many lower extremity health problems in patients with MS (Table 4). Their lower extremities had undergone many biomechanical changes, which could be seen as a functional discrepancy of the load on the lower limbs and walking asymmetry [78].

Changes lower extremity biomechanics and muscle strength caused lower extremity problems which were affecting gait in many ways $[48,54,56]$. The lower extremity problems caused walking difficulties which were seen in the length of the step or the walking speed [44, $47,48,54,73]$. Walking and mobility problems and a limited range of motion in the lower limb joints were the most bothersome symptoms in patients with MS [44]. Perceived fatigue shortened the walking distance, $[63,67]$ and obesity was linked to a slower walking speed with shorter step lengths in patients with MS [58]. The altered lower extremity mechanics in these patients reflected a strength deficit compared with healthy controls during walking [56]. Patients with MS had increased coactivation in the knee and ankle muscles during the single or double support phases of the gait. This increased coactivation of muscles was associated with impaired postural stability and was a compensatory mechanism, where a patient with MS tried to walk as safely as possible [46]. Impaired postural balance resulted in decreased maximal walking performance and walking speed $[48,54]$.

Spasticity in the lower extremities was common (Table 4), [75] resulting in reduced balance [81] and creating an altered gait pattern characterised by reduced speed, rhythm, stride length and swing phase and increased double support time [68]. Muscle weaknesses in the lower limbs was prevalent in patients with MS and resulted in a slower sitting-to-standing time [47] and reduced balance [51]. Thus, reduced balance was related to slower walking velocity [54]. In the foot and ankle, pes cavus, claw toes, ankle equinus [75] and lower extremity oedema were prevalent [80]. Neuropathic pain and sudomotor dysfunction and elevated vibration perception of the feet were also common and associating with neurological disability caused by MS [60].

Some interventions aimed to support lower extremity health in patients with MS. Most of the intervention studies $(n=12)$ were focused on improving lower extremity muscle strength, $[52,53,64,83]$ walking, $[53,55$, $65,69,70,74,76,77,83]$ balance, [51, 52] mobility [52] or kinematics in the lower extremities [76]. The interventions varied from various physical training methods to foot orthoses. Eight week progressive lower body resistance training significantly improved leg extensor 
Table 3 Methods of assessing lower extremity health in patients with MS

\begin{tabular}{|c|c|c|}
\hline Measurement focus & Data collection method & References \\
\hline \multirow[t]{2}{*}{ Gait (biomechanics) } & $\begin{array}{l}\text { 3D or visual gait analysis of gait parameters } \\
\text { (e.g. step width, swing, stride length) }\end{array}$ & {$[46,54-56,59,67-70,73,76,77,79,84]$} \\
\hline & Fast walking speed & {$[48,53]$} \\
\hline \multirow[t]{6}{*}{ Gait (ability) } & 2-min walk test & {$[49,53,58,59,61]$} \\
\hline & 10-m walk test & {$[18,70]$} \\
\hline & 5-min walk test & [74] \\
\hline & Stair climb test & {$[18,61]$} \\
\hline & Bessou's locometer & {$[81]$} \\
\hline & Multiple Sclerosis Walking Scale (self-reported) & {$[58,65,67,72,74,81]$} \\
\hline \multirow[t]{3}{*}{ Mobility } & Timed up-and-go test & {$[18,48,49,52,58,59,70,81]$} \\
\hline & Timed 25-ft walk & {$[44,48,49,54,58-61,65,74,77,79,81,83]$} \\
\hline & 500-m walk & [77] \\
\hline \multirow[t]{2}{*}{ Aerobic capacity and endurance } & 6-min walk test & {$[18,45,58,62,63,70,79,81]$} \\
\hline & One-legged cycling test & {$[62]$} \\
\hline Physical activity & International Physical Activity Questionnaire & {$[67]$} \\
\hline \multirow[t]{4}{*}{ Muscle strength } & Isokinetic dynamometry & {$[49,55,61]$} \\
\hline & Isometric dynamometry & {$[18,51,57,61-64,77,79]$} \\
\hline & Dynamometer & {$[54,82,83]$} \\
\hline & Sit to stand (5 times) & {$[61]$} \\
\hline \multirow[t]{2}{*}{ Muscle endurance } & Number of repetitions on seated leg press & {$[53]$} \\
\hline & 3-min stepping test & {$[55]$} \\
\hline \multirow[t]{7}{*}{ Muscle stiffness and spasticity } & Multiple Sclerosis Spasticity Scale & {$[53]$} \\
\hline & Ashworth Scale & {$[50,71,81]$} \\
\hline & Tardieu Scale & [71] \\
\hline & Functional ambulatory score & {$[65]$} \\
\hline & Resistance to passive range of motion & {$[75]$} \\
\hline & Tendon reflexes & {$[75]$} \\
\hline & Dynamic or passive range of motion & {$[68,69,76]$} \\
\hline \multirow[t]{7}{*}{ Balance } & Stabilometry or posturography & {$[48,54,63,72]$} \\
\hline & Obstacle negotiation & [70] \\
\hline & Timed standing on one leg & {$[50,51]$} \\
\hline & Static postural control & {$[58]$} \\
\hline & Centre of pressure & {$[52,79]$} \\
\hline & Activities-specific Balance Confidence Scale & {$[67,74,81]$} \\
\hline & Berg Balance Scale & {$[18,49,80,81]$} \\
\hline \multirow[t]{8}{*}{ Specific foot assessments } & Vibration perception & {$[50,54,60]$} \\
\hline & Force distribution & {$[66,78]$} \\
\hline & Plantar pressure & {$[66,78]$} \\
\hline & Neuropathic pain & {$[60]$} \\
\hline & Sudomotor function & {$[60]$} \\
\hline & Oedema: Fovea's sign, Stemmer's sign & {$[80]$} \\
\hline & Sensation: Semmes-Weinstein monofilament & {$[50]$} \\
\hline & Foot deformities & {$[75]$} \\
\hline
\end{tabular}


Table 4 Lower extremity health problems in patients with MS

\begin{tabular}{ll}
\hline Lower extremity health problem & References \\
\hline Decreased muscle strength in lower limbs & {$[46,47,51,56,62,82]$} \\
Impaired balance & {$[48,50,51,67]$} \\
Walking dysfunction & {$[44,54,59,66,67,73,78,79,82,84]$} \\
Decreased pressure sensation & {$[50]$} \\
Decreased vibration sensation & {$[50,60]$} \\
Sudomotor dysfunction & {$[60]$} \\
Oedema & {$[80]$} \\
Pes cavus & {$[75]$} \\
Claw toes & {$[75]$} \\
Spasticity & {$[68,81]$} \\
\hline
\end{tabular}

power, [52] knee extension, plantarflexion and stepping performance, [83] and it also had positive effects on walking ability [55]. Supervised muscle power training for the knee extensors lasting 12 weeks improved peak muscle power and maximal voluntary isometric contraction of the knee extensors [64]. Physical activity program for 24 weeks consisting of aerobic and strength training resulted improvements is gait stride length, speed and cadence [65] and muscle endurance [69]. Aerobic training improved the passive range of movement in the hips, but it had only a minimal effect on gait abnormalities [76]. Virtual reality treadmill training for 6 weeks improved balance, walking endurance and gait kinematics [70]. Mixed evidence was found for the effects of foot orthoses [45, 72, $74]$ and whole-body vibration $[49,57]$ as interventions. Ankle-foot orthoses and functional electrical stimulation improved walking speed in patients with MS with foot drop [74]. Whereas dynamic foot orthoses increased body sway and changed the centre of pressure position [72]. Powered ankle-foot orthosis did not improve walking endurance of patients with MS [45].

\section{Discussion}

Research on lower extremity health in patients with MS is an important and necessary aspect of rehabilitation research. This review highlights the importance of future research on the topic. On the basis of the results, it is evident that lower extremity research among patients with MS has focused strongly on gait and lower extremity muscle strength. Little emphasis has been placed on foot or ankle problems. It is understandable that the focus has been on lower extremity strength, as maintaining the ability to move is important for functional ability. However, sometimes relatively small changes in foot or ankle biomechanics and in foot health can affect walking ability; thus, more attention on this is needed in future.

The research methods applied in the studies were varied. Performance assessments were undertaken with validated and widely used methods such as timed 25-Foot
Walk and 6-Minute Walk Test. The methods were strongly focusing on objective assessment of lower extremity health. Patients' subjective perspective to lower extremity health was rarely under investigation. The use of qualitative methods such as interviews or written diaries could provide useful information about patients' experiences of living with MS and lower extremity problems including how they manage in daily life in terms of walking, foot self-care and footwear which all are important while maintaining or promoting lower extremities. In addition, the use of information technology, such as active wristbands, could produce detailed followup information about level of physical activity and this information could be analysed against lower extremity health status.

The design of the research reviewed was traditional and in line with the research methods. Future studies could focus on more versatile research designs. Follow-up studies with many measurement points could provide evidence of how lower extremity health, specifically foot health, alters over time or in relation to MS disease activity. In addition, observational studies could provide important information how patients with MS care for their feet. With this kind of information, targeted interventions could be developed and tested in order to support patients with MS during the trajectory of the disease.

Many patients with MS have problems with the lower extremities of which the most widespread problems relate to reduced lower limb muscle strength, impaired balance and walking dysfunction. Moreover, pes cavus, claw toes, oedema and altered foot sensation were common. All these problems have a direct effect on quality of life [85]; thus, it is important to study them. In future, the use of wearable technology [86] or other new technologies could provide a new way to assess walking ability, balance and muscle strength in patients' actual everyday circumstances. This kind of information could be used as the basis for future interventions and technological innovations. 
One important aspect of lower extremity health is foot self-care, but there is limited evidence of how patients with MS manage this. Therefore, it is important to identify potential gaps in foot care knowledge and habits among patients with MS, which could be done by using, for example, information technology for communication. Moreover, the hindering and promoting factors for lower extremity health, including foot health, should be investigated in order to help develop interventions that support foot self-care.

Future research needs to investigate the foot problems experienced by patients with MS. There is limited evidence of foot health in patients with MS as only one study identified in this review focused directly on foot health revealing pes cavus and claw toes common in patients with MS [75]. The particular study focused only foot structural deformities omitting for example skin and nail problems and foot pain. Therefore in order to gain a full picture of foot health status in patients with MS a large scale foot health assessment studies are needed. Changes in foot and ankle biomechanics or muscle strength in the foot can alter gait [66] and decrease functional ability. More specifically, changes in foot biomechanics can cause changes in the skin, such as corns and calluses, which, because they may be painful, can lead to altered foot biomechanics increasing tissue stress and thus impacting on gait [87]. Therefore, a systematic and thorough foot and lower extremity assessment is needed to conduct with methods combining the assessment of mechanically-based pathologies in the skin, tissue stress and foot, ankle and lower extremity biomechanics.

Assessment of foot problems and timely provided care is important in patients with MS. If foot problems are left uncared they can have long-term consequences on a person's overall health. To support identification of foot problems, there is a need to develop a systematic assessment framework for evaluating the impact of MS on the lower limbs and feet. This information could then be used in both clinical and research contexts. The impact of assessing foot problems, and the resulting foot-health interventions, needs to be evaluated in the clinical and research contexts. Patients with MS could benefit from an intervention study where the effectiveness of professional foot care and individual foot self-care outcomes are assessed in order to improve foot health.

\section{Strengths and limitations}

This review has some strengths and limitations that must be considered when interpreting the results. The literature search was conducted in the Medline (PubMed), CINAHL and Cochrane Library databases. Both of these databases are scientific, international and widely used, and their coverage of research in the field of health sciences is comprehensive [88]. The literature search was conducted using a combination of $\mathrm{MeSH}$ terms (in Medline) and Major Headings (in CINAHL) related to MS and keywords related to lower extremity health. The use of MeSH or Major Headings was considered appropriate because MS is a universally agreed term and there is no synonym for the disease. On the other hand, several synonyms were used for lower extremity health in order to ensure a comprehensive approach to the topic. Despite the careful search term planning, some terms might have been missed; thus, the coverage of the review could have been limited. However, the search produced more than 400 hits, the vast majority of which focused on MS.

The major limitation of this review relates to the analysis of the studies that were included. The studies were heterogeneous and were conducted using different study designs. The variation in the research methods and the results posed challenges for the analysis. Instead of searching for in-depth information about lower extremity health in patients with MS, a decision to remain at the general descriptive level was made within the research team. This decision was in line with the general definition of systematic scoping reviews, which usually focus on identifying the potential size and scope of the available research literature [89]. Moreover, the heterogeneous nature and methodological diversity of the studies restricted the possibility to conduct meta-analysis. In future, a review focusing on studies with similar designs could be conducted in order to advance in-depth knowledge of lower extremity health in patients with MS. Despite these limitations, this review produced a summary and evidence of current research and demonstrated the need for further research.

\section{Conclusions}

This systematic scoping review revealed that MS affects lower limb and foot health in ways that have the potential to affect patients' daily life. However, the extent of these problems is unclear, and this is in due to a dearth of research that focuses on lower limb and foot health in this patient group. It is important to identify foot problems at an early stage to facilitate the provision of appropriate interventions in a timely manner. It is evident that there needs to be more focus on foot problems, both in the clinical environment and in the context of research.

\footnotetext{
Abbreviations

CINAHL: The Cumulative Index of Nursing and Allied Health Literature; EDSS: Expanded Disability Status Scale; MeSH: Medical Subject Headings; MS: Multiple sclerosis; PRISMA: The Preferred Reporting Items for Systematic Reviews and Meta-Analyses
}

Acknowledgements

None. 


\section{Authors' contributions}

MS designed the study. MS and A-ML collected and analysed the data. MS A-ML drafted the article. JR and HL-K critically revised the article for important intellectual content. All authors read and approved the final version of the manuscript.

\section{Funding}

None.

\section{Availability of data and materials}

The datasets used and/or analysed during the current study are available from the corresponding author on reasonable request.

\section{Ethics approval and consent to participate}

Not applicable.

\section{Consent for publication}

Not applicable.

\section{Competing interests}

The authors declare that they have no competing interests.

\section{Author details}

${ }^{1}$ Department of Nursing Science, University of Turku, 20014 Turku, Finland.

${ }^{2}$ Turku University Hospital, Turku, Finland. ${ }^{3}$ Finnish Neuro Society, Masku,

Finland. ${ }^{4}$ Department of Neurology, University of Turku, Turku, Finland.

\section{Received: 22 April 2020 Accepted: 20 August 2020}

\section{Published online: 27 August 2020}

\section{References}

1. Compston A, Coles A. Multiple sclerosis. Lancet. 2008;372:1502-17.

2. GBD 2016 Multiple Sclerosis Collaborators. Global, regional, and national burden of multiple sclerosis 1990-2016: a systematic analysis for the Global Burden of Disease Study 2016. Lancet Neurol. 2019;18:269-85.

3. Pirttisalo AL, Soilu-Hänninen M, Sipilä J. Multiple sclerosis epidemiology in Finland: regional differences and high incidence. Acta Neurol Scand. 2019; 139:353-9.

4. Kurtzke JF. Rating neurologic impairment in multiple sclerosis: an expanded disability status scale (EDSS). Neurology. 1983;33:1444-52.

5. Hobart JC, Riazi A, Lamping DL, et al. Measuring the impact of MS on walking ability: the 12-item MS walking scale (MSWS-12). Neurology. 2013; 60:31-6.

6. Carling A, Forsberg A, Nilsagård Y. Falls in people with multiple sclerosis: experiences of 115 fall situations. Clin Rehabil. 2018;32:526-35. https://doi. org/10.1177/0269215517730597.

7. Comber L, Sosnoff JJ, Galvin R, et al. Postural control deficits in people with multiple sclerosis: a systematic review and meta-analysis. Gait Posture. 2018; 61:445-52. https://doi.org/10.1016/j.gaitpost.2018.02.018.

8. Giannì C, Prosperini L, Jonsdottir J, et al. A systematic review of factors associated with accidental falls in people with multiple sclerosis: a metaanalytic approach. Clin Rehabil. 2014;28:704-16. https://doi.org/10.1177/ 0269215513517575.

9. Nilsagård $Y$, Gunn $H$, Freeman J, et al. Falls in people with MS, an individual data meta-analysis from studies from Australia, Sweden, United Kingdom and the United States. Mult Scler. 2015;21:92-100.

10. Mazumder R, Lambert WE, Nguyen $\mathrm{T}$, et al. Fear of falling is associated with recurrent falls in people with multiple sclerosis: a longitudinal cohort study. Int J MS Care. 2015:17:164-70.

11. Hatton AL, Rome K. Falls, footwear, and podiatric interventions in older adults. Clin Geriatr Med. 2019;35:161-71

12. Gunn $H$, Markevics S, Haas B, et al. The effectiveness of interventions to reduce falls and improve balance in adults with multiple sclerosis. Arch Phys Med Rehabil. 2015;96:1898-912. https://doi.org/10.1016/j.apmr.2015.05.018.

13. Mañago MM, Hebert JR, Kittelson J, et al. Contributions of ankle, knee, hip, and trunk muscle function to gait performance in people with multiple sclerosis: a cross-sectional analysis. Phys Ther. 2018;98:595-604. https://doi. org/10.1093/ptj/pzy048.

14. Comber L, Galvin R, Coote S. Gait deficits in people with multiple sclerosis: a systematic review and meta-analysis. Gait Posture. 2017:51:25-35. https:// doi.org/10.1016/j.gaitpost.2016.09.026.
15. Sá MJ. Exercise therapy and multiple sclerosis: a systematic review. J Neurol. 2014:261:1651-61. https://doi.org/10.1007/s00415-013-7183-9.

16. McLoughlin JV, Lord SR, Barr CJ, et al. Dorsiflexion assist orthosis reduces the physiological cost and mitigates deterioration in strength and balance associated with walking in people with multiple sclerosis. Arch Phys Med Rehabil. 2015;96:226-32. https://doi.org/10.1016/j.apmr.2014.09.005.

17. Gervasoni E, Parelli R, Uszynski M, et al. Effects of functional electrical stimulation on reducing falls and improving gait parameters in multiple sclerosis and stroke. PM R. 2017;9:339-47. https://doi.org/10.1016/j.pmrj.2016.10.019.

18. Hayes $\mathrm{S}$, Galvin R, Kennedy C, et al. Interventions for preventing falls in people with multiple sclerosis. Cochrane Database of Syst Rev. 2019;11. https://doi.org/10.1002/14651858.CD012475.pub2.

19. Svoboda Z, Janura M, Kutilek P, et al. Relationships between movements of the lower limb joints and the pelvis in open and closed kinematic chains during a gait cycle. J Hum Kinet. 2016;51:37-43. https://doi.org/10.1515/ hukin-2015-0168.

20. Menz HB. Chronic foot pain in older people. Maturitas. 2016;91:110-4 https://doi.org/10.1016/j.maturitas.2016.06.011.

21. Hendry GJ, Fenocchi L, Woodburn J, et al. Foot pain and foot health in an educated population of adults: results from the Glasgow Caledonian University Alumni Foot Health Survey. J Foot Ankle Res. 2018;11:48. https:// doi.org/10.1186/s13047-018-0290-1.

22. González-Martín C, Alonso-Tajes F, Pérez-García S, et al. Hallux valgus in a random population in Spain and its impact on quality of life and functionality. Rheumatol Int. 2017;37:1899-907. https://doi.org/10.1007/ s00296-017-3817-z.

23. Pita-Fernandez S, González-Martín C, Seoane-Pillado T, et al. Podiatric medical abnormalities in a random population sample 40 years or older in Spain. J Am Podiatr Med Assoc. 2014;104:574-82.

24. Pita-Fernandez S, Gonzalez-Martin C, Alonso-Tajes F, et al. Flat foot in a random population and its impact on quality of life and functionality. J Clin Diagn Res. 2017;11:LC22-7. https://doi.org/10.7860/JCDR/2017/24362.9697.

25. Bennett PJ. Types of foot problems seen by Australian podiatrists. Foot. 2012;22:40-5. https://doi.org/10.1016/j.foot.2011.11.002

26. Salvotelli L, Stoico V, Perrone F, et al. Prevalence of neuropathy in type 2 diabetic patients and its association with other diabetes complications: the Verona diabetic foot screening program. J Diabetes Complicat. 2015;29: 1066-70. https://doi.org/10.1016/j.jdiacomp.2015.06.014.

27. van Netten JJ, Price PE, Lavery LA, et al. Prevention of foot ulcers in the atrisk patient with diabetes: a systematic review. Diabetes Metab Res Rev. 2016;32:84-98. https://doi.org/10.1002/dmrr.2701.

28. Stolt $\mathrm{M}$, Suhonen $\mathrm{R}$, Leino-Kilpi $\mathrm{H}$. Foot health in patients with rheumatoid arthritis-a scoping review. Rheumatol Int. 2017;37:1413-22. https://doi.org/ 10.1007/s00296-017-3699-0.

29. Otter SJ, Kumar S, Gow P, et al. Patterns of foot complaints in systemic lupus erythematosus: a cross sectional survey. J Foot Ankle Res. 2016;9:10. https://doi.org/10.1186/s13047-016-0143-8.

30. Phillips A, Mehl AA. Diabetes mellitus and the increased risk of foot injuries. J Wound Care. 2015;24:4-7. https://doi.org/10.12968/jowc.2015.24.Sup5b.4.

31. Engberg S, Kirketerp-Møller K, Ullits Andersen $\mathrm{H}$, et al. Incidence and predictors of recurrent and other new diabetic foot ulcers: a retrospective cohort study. Diabet Med. 2019;36:1417-23. https://doi.org/10.1111/dme.13964.

32. Menz HB, Auhl M, Spink MJ. Foot problems as a risk factor for falls in community-dwelling older people: a systematic review and meta-analysis. Maturitas. 2018;118:7-14. https://doi.org/10.1016/.maturitas.2018.10.001.

33. Mickle KJ, Munro BJ, Lord SR, et al. Gait, balance and plantar pressures in older people with toe deformities. Gait Posture. 2011;34:347-51. https://doi. org/10.1016/j.gaitpost.2011.05.023.

34. Chopra S, Moerenhout K, Crevoisier X. Characterization of gait in female patients with moderate to severe hallux valgus deformity. Clin Biomech. 2015;30:629-35. https://doi.org/10.1016/j.clinbiomech.2015.03.021.

35. Lee CR, Kim MK. The effects on muscle activation of flatfoot during gait according to the velocity on an ascending slope. J Phys Ther Sci. 2014;26: 675-7. https://doi.org/10.1589/jpts.26.675.

36. Kim MK. Foot pressure analysis of adults with flat and normal feet at different gait speeds on an ascending slope. J Phys Ther Sci. 2015;27:37679. https://doi.org/10.1589/jpts.27.3767.

37. Stubbs $B$, Binnekade $T$, Eggermont $L$, et al. Pain and the risk for falls in community-dwelling older adults: systematic review and meta-analysis. Arch Phys Med Rehabil. 2014;95:175-87.e9. https://doi.org/10.1016/j. apmr.2013.08.241. 
38. Mickle KJ, Munro BJ, Lord SR, et al. Cross-sectional analysis of foot function, functional ability, and health-related quality of life in older people with disabling foot pain. Arthritis Care Res. 2011;63:1592-8. https://doi.org/10. 1002/acr.20578.

39. Larocca NG. Impact of walking impairment in multiple sclerosis: perspectives of patients and care partners. Patient. 2011;4:189-201.

40. Lopez-Lopez D, Becerro-de-Bengoa-Vallejo R, Losa-Iglesias ME, et al. Evaluation of foot health related quality of life in individuals with foot problems by gender: a cross-sectional comparative analysis study. BM Open. 2018;8:e023980. https://doi.org/10.1136/bmjopen-2018-023980.

41. Arksey H, O'Malley L. Scoping studies: towards a methodological framework. Int J Soc Res Methodol. 2005;8:1. https://doi.org/10.1080/ 1364557032000119616

42. Tricco AC, Lillie E, Zarin W, et al. PRISMA extension for scoping reviews (PRISMA-ScR): checklist and explanation. Ann Intern Med. 2018. 169:467-73.

43. Hong QN, Gonzalez-Reyes A, Pluye P. Improving the usefulness of a tool for appraising the quality of qualitative, quantitative and mixed methods studies, the mixed methods appraisal tool (MMAT). J Eval Clin Pract. 2018;24: 459-67.

44. Pike J, Jones $\mathrm{E}$, Rajagopalan $\mathrm{K}$, et al. Social and economic burden of walking and mobility problems in multiple sclerosis. BMC Neurol. 2012;12:1-8. https://doi.org/10.1186/1471-2377-12-94.

45. Boes MK, Bollaert RE, Kesler RM, et al. Six-minute walk test performance in persons with multiple sclerosis while using passive or powered ankle-foot Orthoses. Arch Phys Med Rehabil. 2018;99:484-90. https://doi.org/10.1016/j. apmr.2017.06.024.

46. Boudarham J, Hameau S, Zory R, et al. Coactivation of lower limb muscles during gait in patients with multiple sclerosis. PLOS ONE. 2016;11:1-13. https://doi.org/10.1371/journal.pone.0158267.

47. Bowser B, O'Rourke S, Brown CN, et al. Sit-to-stand biomechanics of individuals with multiple sclerosis. Clin Biomech. 2015;30:788-94. https://doi. org/10.1016/j.clinbiomech.2015.06.012.

48. Brincks J, Andersen ED, Sorensen $\mathrm{H}$, et al. Impaired postural balance correlates with complex walking performance in mildly disabled persons with multiple sclerosis. NeuroRehabilitation. 2017;41:227-35. https://doi.org/ 10.3233/NRE-171475.

49. Broekmans T, Roelants M, Alders G, et al. Exploring the effects of a 20-week whole-body vibration training programme on leg muscle performance and function in persons with multiple sclerosis. J Rehabil Med. 2010;42:866-72. https://doi.org/10.2340/16501977-0609.

50. Citaker S, Gunduz AG, Guclu MB, et al. Relationship between foot sensation and standing balance in patients with multiple sclerosis. Gait Posture. 2011; 34:275-8. https://doi.org/10.1016/j.gaitpost.2011.05.015.

51. Citaker S, Guclu-Gunduz A, Yazici G, et al. Relationship between lower extremity isometric muscle strength and standing balance in patients with multiple sclerosis. NeuroRehabilitation. 2013;33:293-8. https://doi.org/10. 3233/NRE-130958

52. DeBolt LS, McCubbin JA. The Effects of Home-Based Resistance Exercise on Balance, Power, and Mobility in Adults with Multiple Sclerosis. Arch Phys Med Rehabil. 2004;85:290-7. https://doi.org/10.1016/j.apmr.2003.06.003.

53. Dodd KJ, Taylor NF, Shields N, et al. Progressive resistance training did not improve walking but can improve muscle performance, quality of life and fatigue in adults with multiple sclerosis: a randomized controlled trial. Mult Scler J. 2011;17:1362-74. https://doi.org/10.1177/1352458511409084.

54. Fritz NE, Newsome SD, Eloyan A, et al. Longitudinal relationships among posturography and gait measures in multiple sclerosis. Neurology. 2015;84: 2048-56. https://doi.org/10.1212/WNL.0000000000001580.

55. Gutierrez GM, Chow JW, Tillman MD, et al. Resistance training improves gait kinematics in persons with multiple sclerosis. Arch Phys Med Rehabil. 2005; 86:1824-9. https://doi.org/10.1016/j.apmr.2005.04.008.

56. Huisinga JM, Schmid KK, Filipi M, et al. Gait mechanics are different between healthy controls and patients with multiple sclerosis. J Appl Biomech. 2013;29:303-11.

57. Jackson KJ, Merriman HL, Vanderburgh PM, et al. Acute effects of wholebody vibration on lower extremity muscle performance in persons with multiple sclerosis. J Neurol Phys Ther. 2008;32:171-6. https://doi.org/10. 1097/NPT.0b013e31818ee760.

58. Kalron A. Relationship of obesity with gait and balance in people with multiple sclerosis. Am J Phys Med Rehabil. 2017;96:140-5. https://doi.org/10. 1097/PHM.0000000000000552.
59. Kalron A. Association between gait variability, falls and mobility in people with multiple sclerosis: A specific observation on the EDSS 4.0-4.5 level. NeuroRehabilitation. 2017;40:579-85. https://doi.org/10.3233/NRE-171445.

60. Khan A, Kamran S, Ponirakis G, et al. Peripheral neuropathy in patients with multiple sclerosis. PLoS One. 2018;13:1-8. https://doi.org/10.1371/journal. pone.0193270.

61. Kjølhede T, Vissing K, Langeskov-Christensen D, et al. Relationship between muscle strength parameters and functional capacity in persons with mild to moderate degree multiple sclerosis. Mult Scler Relat Disord. 2015;4:151-8. https://doi.org/10.1016/j.msard.2015.01.002.

62. Larson RD, McCully KK, Larson DJ, et al. Bilateral differences in lower-limb performance in individuals with multiple sclerosis. JRD. 2013;50:215-22. https://doi.org/10.1682/2011.10.0189.

63. McLoughlin JV, Barr C, Crotty M, et al. Six minutes of walking leads to reduced lower limb strength and increased postural sway in people with multiple sclerosis. NeuroRehabilitation. 2014;35:503-8. https:/doi.org/10.3233/NRE-141143.

64. Medina-Perez C, de Souza-Teixeira F, Fernandez-Gonzalo R, et al. Effects of highspeed power training on muscle strength and power in patients with multiple sclerosis. JRRD. 2016:53:359-68. https://doi.org/10.1682/JRRD.2014.08.0186.

65. Motl RW, Smith DC, Elliott J, et al. Combined training improves walking mobility in persons with significant disability from multiple sclerosis: a pilot study. J Neurol Phys Ther. 2012;36:32-7. https://doi.org/10.1097/NPT. Ob013e3182477c92.

66. Neamțu MC, Rusu L, Marin M, et al. Morphofunctional aspects of lower limb in multiple sclerosis. Romanian J Morphol Embryol. 2012;53:117-20.

67. Nogueira LAC, Teixeira L, Sabino P, et al. Gait characteristics of multiple sclerosis patients in the absence of clinical disability. Disabil Rehabil. 2013: 35:1472-8. https://doi.org/10.3109/09638288.2012.738760.

68. Pau M, Coghe $\mathrm{G}$, Corona F, et al. Effect of spasticity on kinematics of gait and muscular activation in people with multiple sclerosis. J Neurol Sci. 2015; 358:339-44. https://doi.org/10.1016/j.ns.2015.09.352.

69. Pau M, Corona F, Coghe G, et al. Quantitative assessment of the effects of 6 months of adapted physical activity on gait in people with multiple sclerosis: a randomized controlled trial. Disabil Rehabil. 2017:40:144-51. https://doi.org/10.1080/09638288.2016.1244291.

70. Peruzzi $A$, Zarbo IR, Cereatti $A$, et al. An innovative training program based on virtual reality and treadmill: effects on gait of persons with multiple sclerosis. Disabil Rehabil. 2017:39:1557-63. https://doi.org/10.1080/09638288. 2016.1224935

71. Picelli A, Vallies G, Chemello E, et al. Is spasticity always the same? An observational study comparing the features of spastic equinus foot in patients with chronic stroke and multiple sclerosis. J Neurol Sci. 2017;380: 132-6. https://doi.org/10.1016/j.ns.2017.07.026

72. Ramdharry GM, Marsden JF, Day BL, et al. De-stabilizing and training effects of foot orthoses in multiple sclerosis. Mult Scler. 2006;12:219-26. https://doi. org/10.1191/135248506ms1266oa.

73. Remelius JG, Jones SL, House JD, et al. Gait impairments in persons with multiple sclerosis across preferred and fixed walking speeds. Arch Phys Medi Rehabil. 2012:93:1637-42. https://doi.org/10.1016/j.apmr.2012.02.01.

74. Renfrew LM, Paul L, McFadyen A, et al. The clinical- and cost-effectiveness of functional electrical stimulation and ankle-foot orthoses for foot drop in multiple sclerosis: a multicentre randomized trial. Clin Rehabil. 2019;33: 1150-62. https://doi.org/10.1177/0269215519842254.

75. Rivera-Domingues M, DiBenedetto MD, Frisbie JH, et al. Pes Cavus and claw toes deformity in patients with spinal cord injury and multiple sclerosis. Paraplegia. 1978;16:375-82

76. Rodgers MM, Mulcare JA, King DL, et al. Gait characteristics of individuals with multiple sclerosis before and after a 6-month aerobic training program. J Rehabil Res Dev. 1999;36:183-8.

77. Romberg A, Virtanen A, Ruutiainen J, et al. Effects of a 6-month exercise program on patients with multiple sclerosis: a randomized study. Neurology. 2004;63:2034-8.

78. Rusu L, Neamtu MC, Rosulescu E, et al. Analysis of foot and ankle disorders and prediction of gait in multiple sclerosis rehabilitation. Eur J Med Res. 2014;19:1-10. https://doi.org/10.1186/s40001-014-0073-5.

79. Sandroff BM, Sosnoff JJ, Motl RW. Physical fitness, walking performance, and gait in multiple sclerosis. J Neurol Sci. 2013;328:70-6. https://doi.org/10. 1016/j.jns.2013.02.021.

80. Solaro C, Messmer Uccelli M, Brichetto G, et al. Prevalence of oedema of the lower limbs in multiple sclerosis patients: a vascular and lymphoscintigraphic study. Mult Scler. 2006;12:659-61. 
81. Sosnoff JJ, Gappmaier E, Frame A, et al. Influence of spasticity on mobility and balance in persons with multiple sclerosis. J Neurol Phys Ther. 2011;35: 129-32. https://doi.org/10.1097/NPT.0b013e31822a8c40.

82. Thoumie P, Mevellec E. Relation between walking speed and muscle strength is affected by somatosensory loss in multiple sclerosis. J Neurol Neurosurg Psychiatry. 2002;73:313-5.

83. White $L$, Castellano V, McCoy SC, et al. Resistance training improves strength and function in multiple sclerosis. Med Sci Sports Exerc. 2004;10: 668-74. https://doi.org/10.1191/1352458504ms1088oa.

84. Yildiz M. The impact of slower walking speed on activities of daily living in patients with multiple sclerosis. Int J Clin Pract. 2012;66:1088-94. https://doi. org/10.1111/ijcp.12003.

85. Kohn CG, Baker WL, Sidovar MF, et al. Walking speed and health-related quality of life in multiple sclerosis. Patient. 2014;7:55-61.

86. Frechette ML, Meyer BM, Tulipani $\amalg$, et al. Next steps in wearable technology and community ambulation in multiple sclerosis. Curr Neurol Neurosci Rep. 2019;19:80. https://doi.org/10.1007/s11910-019-0997-9.

87. Kirby KA. Prescribing Orthoses: has tissue stress theory supplanted root theory? Podiatry Today. 2015;28:36-44.

88. Subirana M, Sola I, Garcia JM, et al. A nursing qualitative systematic review required MEDLINE and CINAHL for study identification. J Clin Epidemiol. 2005:58:20-5.

89. Grant MJ, Booth A. A typology of reviews: an analysis of 14 review types and associated methodologies. Health Inf Libr J. 2009;26:91-108. https://doi. org/10.1111/j.1471-1842.2009.00848.x.

\section{Publisher's Note}

Springer Nature remains neutral with regard to jurisdictional claims in published maps and institutional affiliations.

Ready to submit your research? Choose BMC and benefit from:

- fast, convenient online submission

- thorough peer review by experienced researchers in your field

- rapid publication on acceptance

- support for research data, including large and complex data types

- gold Open Access which fosters wider collaboration and increased citations

- maximum visibility for your research: over $100 \mathrm{M}$ website views per year

At $\mathrm{BMC}$, research is always in progress.

Learn more biomedcentral.com/submissions 